\title{
Effects of L-alanyl-glutamine upon the blood and kidney biochemical parameters in the rat hind limb model of ischemia/reperfusion ${ }^{1}$
}

\author{
Efeitos da L-alanil-glutamina sobre os parâmetros bioquímicos do sangue e do rim no \\ rato submetido à isquemia/reperfusão do membro pélvico
}

\author{
Marcos Antonio Alves², Sérgio Botelho Guimarães ${ }^{3}$, Daniel Aguiar Dias', Paulo Roberto Cavalcante de Vasconcelos ${ }^{4}$, \\ Vicente de Paulo Martins Coelho ${ }^{4}$, Paulo Roberto Leitão de Vasconcelos ${ }^{5}$ \\ 1. From the Department of Surgery, Post-graduation Program (Stricto Sensu), Faculty of Medicine, Federal University of Ceará (UFC), Brazil. \\ 2. Post-Graduate Student (UFC) \\ 3. Master in Surgery, Associate Professor, Faculty of Medicine (UFC) Fortaleza, CE. \\ 4. Medical students (UFC) \\ 5. Professor of Surgery (Ph.D.), Coordinator, Post-graduation Program (Stricto Sensu), Faculty of Medicine (UFC), Fortaleza, CE
}

\begin{abstract}
Purpose: To investigate the effects of l-alanyl-glutamine (Ala-Gln) intragastric administration upon blood and kidney metabolic parameters alterations in rats subjected to ischemia/reperfusion of hind limb. Methods: Forty-eight male rats were randomized in 2 groups offered via gavage either saline $2.0 \mathrm{~mL}$ (G-1) or Ala-Gln solution $0.75 \mathrm{mgKg}^{-1}(\mathrm{G}-2)$ once a day at 7 AM during 7 days. One-hour after the last gavage (Day 7) all rats were submitted to ether anesthesia, laparotomy and clamping of the left iliac artery for $3 \mathrm{~h}$. Kidney and blood samples were collected at the end of ischemic period (3h) and at 1-3-6h during reperfusion period for metabolites (pyruvate, lactate, glucose and ketone bodies) enzymatic analysis. ATP was also assayed in kidney samples. Results: Lactacemia and ketonemia were significantly increased in Ala-Gln treated rats during reperfusion. Kidney pyruvate concentrations were significantly decreased and tissue lactate concentrations were significantly increased during reperfusion (1h and $3 \mathrm{~h}$ ) in G-2 rats compared with respective controls. Glucose, ATP and ketone bodies concentrations were significantly increased in the kidney in L-Ala-Gln treated rats at 3 hours after reperfusion as compared to respective controls. Conclusions: Unilateral hind limb ischemia in L-Ala-Gln pre-treated rats may induce increased lactacemia and increased kidney lactate concentrations, indicating increased glycolytic activity in renal medulla and in other peripheral tissues. Higher ketonemia during reperfusion may reflect a possible increase in ketogenesis due to lower insulin plasma concentration hepatic signaling as a result of increased glucose oxidation in peripheral tissues, caused by the intra-gastric administration of glutamine dipeptide, suggesting also decreased insulin resistance.
\end{abstract}

Key words: Ischemia. Reperfusion. Kidney. Metabolism. Rats, Wistar.

\section{RESUMO}

Objetivo: Investigar alterações dos parâmetros metabólicos no sangue e rim de ratos submetidos à isquemia/reperfusão do membro pélvico. Métodos: Quarenta e oito ratos machos foram distribuídos aleatoriamente em 2 grupos pré-tratados com administração intragástrica de solução salina 2,0 mL (G-1) ou L-alanil-glutamina 0,75 mgKg-1(G-2), uma vez ao dia (7:00h) durante 7 dias. Uma hora após a última gavagem todos os ratos foram anestesiados com éter dietílico, laparotomizados e submetidos ao pinçamento da artéria de ilíaca esquerda, durante 3 horas. Amostras foram coletadas ao término de isquemia e durante a reperfusão (1-3-6h) para determinação das concentrações in vivo de piruvato, lactato, glicose e corpos cetônicos (rim e sangue) e ATP (rim). Resultados: Lactacemia e cetonemia aumentaram no grupo G-2 quando comparadas às aferidas em ratos não-tratados, durante a reperfusão. As concentrações de piruvato diminuíram e de lactato aumentaram significativamente no rim, durante a reperfusão (1h, 3h) em ratos do G-2 comparados aos respectivos controles. Houve um aumento significante nas concentrações renais de glicose, ATP e corpos cetônicos nos ratos tratados com L-alanilglutamina durante a reperfusão (3h). Conclusões: A isquemia do membro pélvico em ratos pré-tratados com L-alanil-glutamina induz aumento da lactacemia e da concentração de lactato renal, indicando atividade glicolítica aumentada na medula renal. A hipercetonemia induzida pela oferta do dipeptídeo sugere cetogênese elevada, sinalizada por possível queda nas concentrações plasmáticas de insulina resultante da maior oxidação de glicose e utilização desse hormônio em tecidos periféricos.

Descritores: Isquemia. Reperfusão. Rim. L-Alanil-glutamina. Metabolismo. Ratos Wistar. 


\section{Introduction}

Ischemia leads to muscle cell energy failure and biochemical alterations. Skeletal muscle represents 70 to $75 \%$ of the whole mass of the inferior members and $80 \%$ of the active metabolism of the organism. Skin, bones and tendons are quite resistant to the hypoxia compared with the skeletal muscle that exhibits an intermediate resistance under the same condition. That relative tolerance to the ischemia is largely owed, not only the low metabolic activity in rest, as well as to the great glycogen and high energy phosphates storage. Under these conditions basic cellular functions are maintained via anaerobic glycolysis. ${ }^{1}$ As early as 1941 investigators have described a renal complex metabolic syndrome secondary to ischemia and reperfusion of lower limbs. ${ }^{2}$ It is well established that exposure to hypoxia results in local tissue injury. The ischemic lesion may be aggravated by the return of fresh blood flow to the ischemic muscle originating the so-called reperfusion syndrome. The ill effects of this syndrome affect not just the local tissues. Remote organs such as the heart, kidneys, liver and lungs may be affected. ${ }^{3}$ The search for efficient substances to revert or attenuate the ischemia/reperfusion injury has been pursued extensively and new drugs are continually being added to the already extensive list of compounds. Glutamine is considered a conditionally essential amino acid, since endogenous glutamine production may be insufficient to meet the increased requirements during catabolic stress conditions. ${ }^{4}$ In addition, glutamine is the most abundant free amino acid in the extra and intracellular compartments, contributing to more than $50 \%$ of the body free amino acid pool and may it may play a significant role in the biochemical changes that occur during ischemia., ${ }^{4,5}$ The aim of this study is to examine the effect of L-alanyl-glutamine intra-gastric pre-treatment in rats subjected to 3-hour hind limb ischemia upon blood and kidney biochemical parameters by assaying in vivo concentrations of pyruvate, lactate, glucose, ketone bodies and ATP (only in kidney tissue).

\section{Methods}

Forty-eight healthy male albino Wistar (Mammalia Rodentia, Muridae, Rattus Norvegicus Albinus) rats obtained from Faculty of Medicine (Federal University of Ceará) Small Animals Laboratory. Rats weighing 400-450 g (average $420 \mathrm{~g}$ ) were used in this study. All animals were of the same breed and raised in controlled environment for research use only. All rat procedures and handling were in compliance with the University of Ceará ethical guidelines for handling and care of experimental animals and the Council for International Organization of Medical Sciences (CIOMS) ethical code for animal experimentation (WHO Chronicle 1985; 39(2):51-6). Approval for experimental use of laboratory animals was obtained from the Commission of Ethics in Animal Research, Federal University of Ceará. The design of the experiment is depicted in Figure 1. All procedures were performed under inhalatory diethyl ether anesthesia. After each surgical intervention rats were allowed to recover from anesthesia and were left free in their cages.

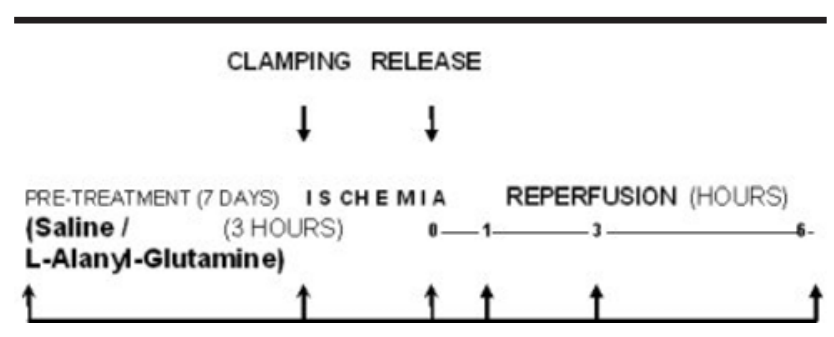

FIGURE 1 - Design of the experiment. Rats were pre-treated with Saline $2.0 \mathrm{~mL}$ or L-Ala-Gln $0.75 \mathrm{mg} \mathrm{Kg}^{-1}$ at 7 AM during 7 days by gavage. One-hour after last gavage all rats were submitted to 3-hour hind limb ischemia (left iliac artery clamping). After 3 hours the clamp was removed. Samples were colleted at the end of the ischemia (0h) and during reperfusion (1, 3 and 6 hours).

\section{Blood and muscle samples}

Samples from arterial blood and kidney were collected at the end of ischemia and 1, 3 and 6 hours later, during reperfusion of the muscle. Kidney samples were obtained from each rat and immediately freeze-clamped in liquid nitrogen for posterior biochemical analysis. Blood samples were placed in glass vials containing perchloric acid and deep frozen until utilized.

\section{Biochemical analysis}

Pyruvate, lactate, glucose and ketone bodies concentrations were assayed in blood and kidney samples according to biochemical methods published elsewhere. ${ }^{6-9}$ Kidney ATP was determined according to Lamprecht \& Trautschold's method. ${ }^{10}$

\section{Statistical analysis}

Metabolites concentrations were calculated as $\mu \mathrm{mol} / \mathrm{g}$ of fresh tissue or $\mu \mathrm{mol} / \mathrm{ml}$ blood and the results were expressed as mean \pm SEM (Standard Error of the Mean). Mann-Whitney and Kruskal-Wallis/Dunn non-parametric tests were used for statistical analysis. Statistical significance was accepted as $\mathrm{p}<0.05$.

\section{Results}

Blood concentrations of pyruvate and lactate were similar in control and experiment groups (Table 1). Lactacemia was significantly increased at $1 \mathrm{~h}(3.21 \pm 0.25 \mathrm{vs}$. $1.63 \pm 0.13)$ and at 3 h post-revascularization ( $2.57 \pm 0.66 \mathrm{vs}$. $0.49 \pm 0.17)$ in Ala-Gln treated rats (G-2) compared with respective controls. Blood lactate levels were significantly decreased in G-1 rats at 6h compared with $0 \mathrm{~h}(0.49 \pm 0.17$ vs. $2.17 \pm 0,33)$ and at 3 h post-revascularization $(0.49 \pm 0.17$ vs. $1.63 \pm 0.13$ ) (Figure 2). Ketonemia was significantly increased in Ala-Gln treated rats during reperfusion (1h: $0.67 \pm 0.11$ vs. 0,37 \pm 0.06 ), (3h: $0.89 \pm 0.22$ vs. $0.37 \pm 0.06$ ) and (6h: $1.33 \pm 0.11$ vs. $0.54 \pm 0.01)$. There was also an increase in blood ketone body concentrations at the end of the study (6h of reperfusion) compared with $0 \mathrm{~h}$ (maximal isquemia) $(1.33 \pm 0.11$ vs. $0.55 \pm 0.04$ ). (Figure 3). 
TABLE 1 - Blood pyruvate and glucose concentrations ( $\mu \mathrm{mol} / \mathrm{ml}$ of whole blood) in saline and Ala-Gln treated rats submitted to hind limb ischemia for 3 hours/reperfusion.

\begin{tabular}{lcccccc}
\hline & & & \multicolumn{4}{c}{ Time of Reperfusion } \\
\cline { 4 - 7 } Metabolite & Group & Treatment & 0h & $1 \mathrm{~h}$ & $3 \mathrm{~h}$ & $6 \mathrm{~h}$ \\
\hline Pyruvate & G-1 & Saline & $0.49 \pm 0.10$ & $0.27 \pm 0.04$ & $0.20 \pm 0.02$ & $0.35 \pm 0.06$ \\
& G-2 & Ala-Gln & $0.24 \pm 0.04$ & $0.28 \pm 0.07$ & $0.33 \pm 0.05$ & $0.36 \pm 0.06$ \\
Glucose & G-1 & Saline & $6.30 \pm 0.99$ & $6.88 \pm 1.09$ & $5.74 \pm 0.62$ & $4.63 \pm 0.46$ \\
& G-2 & Ala-Gln & $7.52 \pm 1.34$ & $7.76 \pm 0.95$ & $6.63 \pm 0.62$ & $4.18 \pm 0.41$ \\
\hline
\end{tabular}

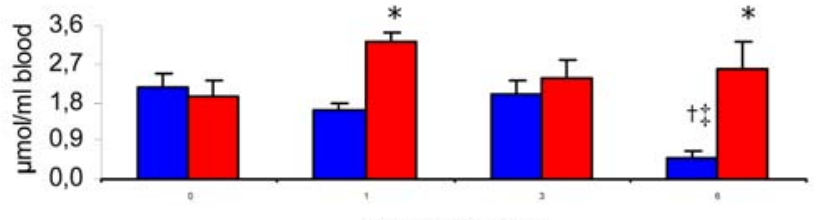

Reperfusion time $\square$ ALA-GLN

Mann-Whitney and Kruskal-Wallis/Dunn non-parametric tests

* $\mathrm{p}<0.05$ compared with respective control

$\dagger \mathrm{p}<0.05$ compared with $\mathrm{T}-0$ in the same group

$\ddagger \mathrm{p}<0.05$ compared with $\mathrm{T}-3$ in the same group

FIGURE 2 - Blood lactate concentrations in saline and L-alanyl-glutamine treated rats.

Kidney pyruvate concentrations were significantly decreased (1h: $0.33 \pm 0.08$ vs. $1.01 \pm 0.19$ and 3 h: $0.37 \pm 0.08$ vs. $1.03 \pm 0.11)$ and lactate concentrations were significantly increased (1h: $3.13 \pm 0.49$ vs. $2.03 \pm 0.55$ and $3 \mathrm{~h}$ : $3.46 \pm 0.42$ vs. $1.81 \pm 0.26)$ after revascularization in $\mathrm{G}-2$ rats compared with respective controls (Figures 4 and 5). Glucose (Figure 6), ATP (Figure 7) and ketone bodies (Figure 8) concentrations in the kidney were increased at 3 h of reperfusion (glucose: $5.76 \pm 0.75$ vs. $2.40 \pm 0.68$ / ATP: $0.75 \pm 0.06$ vs. $0.45 \pm 0.05$ /

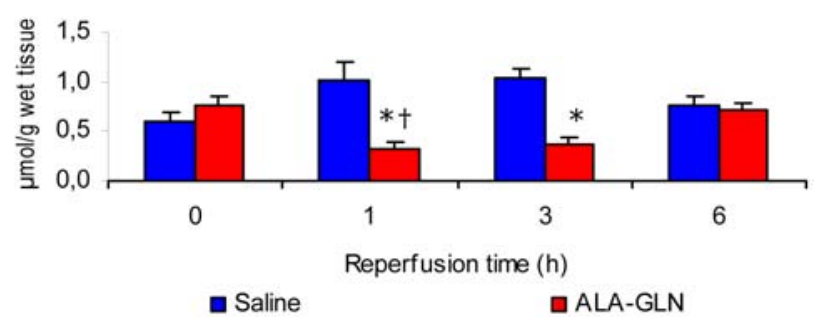

Mann-Whitney and Kruskal-Wallis/Dunn non-parametric tests

$* \mathrm{p}<0.05$ compared with respective control

$\dagger \mathrm{p}<0.05$ compared with $\mathrm{T}-0$ in the same group

FIGURE 4 - Kidney pyruvate concentrations in saline and L-alanyl-glutamine treated rats.

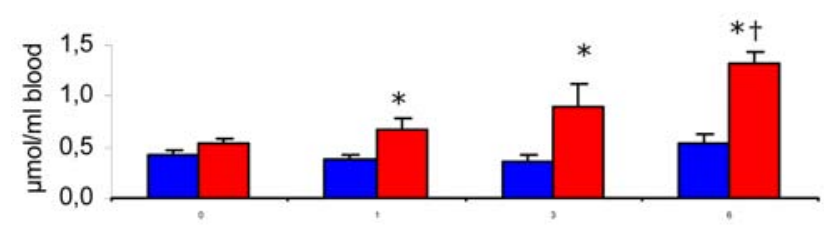

Reperfusion time (h)

Saline

$\square$ ALA-GLN

Mann-Whitney and Kruskal-Wallis/Dunn non-parametric tests

$* \mathrm{p}<0.05$ compared with respective control

$\dagger \mathrm{p}<0.05$ compared with $\mathrm{T}-0$ in the same group

FIGURE 3 - Blood ketone bodies concentrations in saline and L-alanyl-glutamine treated rats.

ketone bodies: $1.03 \pm 0.11$ vs. $0.42 \pm 0,05$ as compared to those found in non-treated rats. There was also a significant increase in ATP concentrations $(0.89 \pm 0.06$ vs. $0.45 \pm 0.05)$ in $\mathrm{G}-1$ rats at the end of the reperfusion period (6h) compared with 3h post-revascularization (Figure 7). G-1 rats presented a significant decrease in ketone bodies concentrations at 3 h, compared with 0 h $(0.42 \pm 0.05$ vs. $1.43 \pm 0.17)$ and $1 \mathrm{~h}(0.42 \pm 0.05$ vs.1.64 \pm 0.29$)$ of reperfusion (Figure 8$)$.

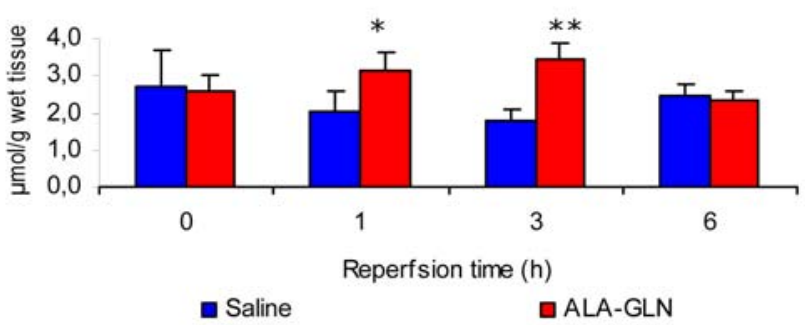

Mann-Whitney and Kruskal-Wallis/Dunn non-parametric tests ** $\mathrm{p}<0.01$ compared with respective control

FIGURE 5 - Kidney lactate concentrations in saline and L-alanyl-glutamine treated rats. 


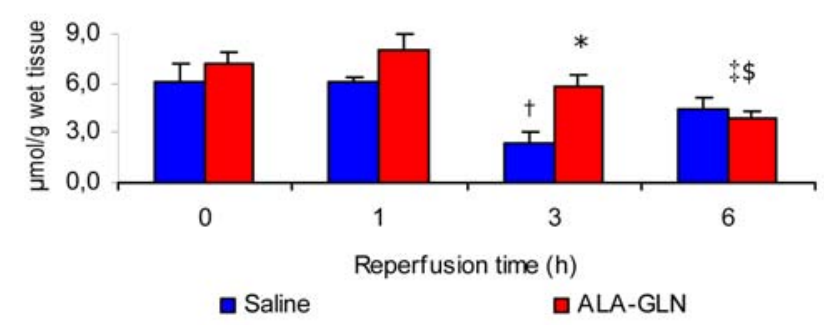

Mann-Whitney and Kruskal-Wallis/Dunn non-parametric tests

$* \mathrm{p}<0.05$ compared with respective control

$\dagger \mathrm{p}<0.05$ compared with $\mathrm{T}-1$ in the same group

$\ddagger \mathrm{p}<0.05$ compared with $\mathrm{T}-0$ in the same group

$\$ \mathrm{p}<0.05$ compared with $\mathrm{T}-1$ in the same group

FIGURE 6 - Kidney glucose concentrations in saline and L-alanyl-glutamine treated rats.

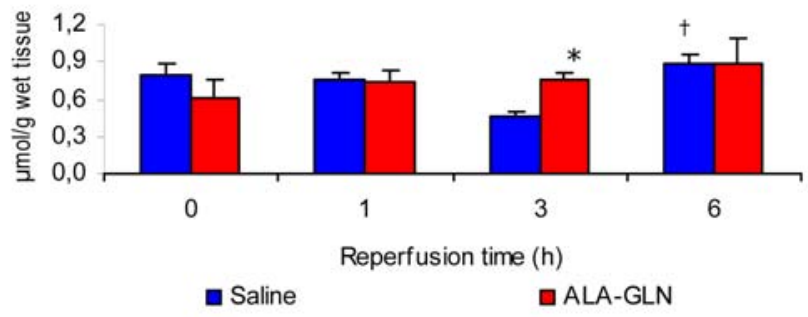

Mann-Whitney and Kruskal-Wallis/Dunn non-parametric tests

$* \mathrm{p}<0.05$ compared with respective control

$\dagger \mathrm{p}<0.05$ compared with $\mathrm{T}-0$ in the same group

FIGURE 7 - Kidney ATP concentrations in saline and L-alanyl-glutamine treated rats.

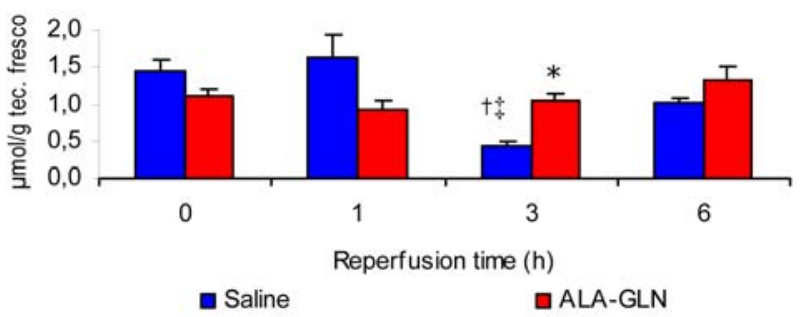

Mann-Whitney and Kruskal-Wallis/Dunn non-parametric tests

$* \mathrm{p}<0.05$ compared with respective control

$\dagger \mathrm{p}<0.05$ compared with $\mathrm{T}-0$ in the same group

$\ddagger \mathrm{p}<0.05$ compared with $\mathrm{T}-1$ in the same group

FIGURE 8 - Kidney ketone bodies concentrations in saline and L-alanyl-glutamine treated rats.

\section{Discussion}

Glutamine free form (L-glutamine) is poorly soluble in aqueous solution, highly unstable in low $\mathrm{pH}$ and high temperatures. Due to such limitations it has been recommended the administration of glutamine precursors, such as glycil-glutamine (Gly-Gln) or L-alanyl-glutamine (Ala-Gln) for their high solubility in water and stability during preparation, storage and administration of nutritional solutions when nutritional therapy is required. Hydrolysis occurs as soon as the dipeptide Ala-Gln is introduced into the blood stream, releasing alanine and glutamine..$^{10}$ The increased blood lactate concentrations in Ala-Gln treated rats points out to an increase in the anaerobic glycolysis in the peripheral tissues. This increased lactacidemia is related to the pro-glycolytic activity of Ala-Gln (Figure 2). This may occur via conversion of glutamine to glutamate in rich glutaminase tissues, activation of the malate/aspartate shuttle and increased availability of $\mathrm{NAD}^{+}$at citosol, which in turn, enhances the conversion of one molecule of glucose into two molecules of pyruvate (glycolitic first step). ${ }^{11,12} \mathrm{It}$ has been shown in glutamate pre-treated rabbits a significant improvement of myocardial function along with elevation of lactate levels due possibly to increased anaerobic production of ATP. ${ }^{13}$ Recent studies have demonstrated that glycolysis may be glutamate-mediated, increasing lactate concentrations in head-injured patients. ${ }^{14}$ In the present study exogenous offer of l-alanyl-glutamine may have led to increased availability of glutamate to glutaminase rich tissues such as kidney medulla. Glutamate in turn stimulates the malate-aspartate shuttle leading to a redox state, rich in $\mathrm{NAD}^{+}$, favorable to glycolytic pathway activation. ${ }^{15}$ Increased blood ketone bodies levels during reperfusion in G-2 as compared to G-1 may be related to increased ketogenesis (Figure 3). The signal to activate ketogenesis is lower plasma insulin. Increased glycolysis in peripheral tissues indicates higher insulin utilization (decreased insulin resistance) and may have an impact in lowering plasma insulin concentrations. The significant decrease in renal pyruvate concentrations during reperfusion (1h and $3 \mathrm{~h}$ ) suggests greater utilization of this metabolite in the anaerobic glycolysis pathway (increased activity of the Krebs cycle in the renal cortex) resulting in decreased total renal pyruvate levels (Figure 4). Kidney medulla metabolic activity is primarily glycolytic, resulting in increased lactate levels due to utilization of glucose for energy production. This activity may explain the significant increase in kidney lactate concentrations during reperfusion (1h, 3h) in rats pre-treated with Ala-Gln (Figure 5). Also, there was increased renal glucose concentration in G-2 animals (3h) may be related to increased uptake of glucose. The same phenomenon was not observed in saline treated rats despite glycemia levels being similar in both groups (Figure 6). The apparent increase in renal ATP (Figure 7) and ketone bodies (Figure 8) in G-2 compared with G-1 during reperfusion (3h) was probably due to a decrease in the concentration of ATP and ketone bodies in G-1. As the concentrations of those metabolites remained similar during the reperfusion period one may believe that this finding could be related to Ala-Gln activity.

\section{Conclusions}

This study has shown that the enteral offer of glutamine dipeptide to animals subjected to unilateral hind limb ischemia, caused by clamping of the left iliac artery, may induce increased lactacemia and distant metabolic alterations in renal biochemical parameters expressed by increased kidney lactate concentrations, indicating elevation of glycolytic activity in renal medulla. The 
elevation in ketonemia may reflect enhanced ketogenesis, possibly due lower plasma insulin as a result of increased insulin utilization (lower insulin resistance) as a consequence of augmented activation of glucose utilization in peripheral tissues, induced by the intra-gastric administration of L-alanyl-glutamine, via activation of malate/aspartate shuttle.

\section{References}

1. Perry MO. Compartment syndromes and reperfusion injury. Surg Clin North Am. 1998; 68:853-64.

2. Bywaters EGL, Beall D. Crush injuries with impairment of renal function. Br Med J. 1941;1:427-32.

3. Grace PA. Ischaemia-reperfusion injury. Brit J Surg. 1994;81:637-47.

4. Souba WW. Nutritional support. N Engl J Med. 1997;336:41-8.

5. Furst P, Pogan K, Stehle P: Glutamine dipeptides in clinical nutrition. Nutrition 1997;13:731-7.

6. Hohorst HJ, Kreutz FH, Bütcher TH. On the metabolite content and the metabolite concentration in the liver of the rat. Biochemische Zeitschrift 1959;332:18-46.

7. Williamson DH, Mellanby J, Krebs HA. Enzymic determinations of the D-(-) â-hydroxybutyric acid and acetoacetic acid in blood. Biochem J. 1962;82:90-6.

8. Hohorst HJ. D-Glucose-6-phosphate and D-fructose-6phosphate: determination with glucose-6-phosphate dehydrogenase and phosphoglucose isomerase. In: Bergmeyer HU. Methods of enzymatic analysis. London: Weinheim/Academic Press;1963. p.134-8.
9. Slein MW. Determination with hexokinase and glucose6-phosphate dehydrogenase. In: Bergmeyer HU. Methods of enzymatic analysis. London: Weinheim/ Academic Press; 1963. p.117-23.

10. Lamprecht, W.;Trautschold, I. Determination with hexokinase and glucose-6-phosphate dehydrogenase. In: Bergmeyer HU. (Ed). Methods of enzymatic analysis. London: Weinheim/Academic Press; 1963. p. 543-51.

11. Souba WW. Intestinal glutamine metabolism and nutrition. J Nutr Biochem. 1993;4:2-9.

12. Bezerra Filho JE, Guimarães SB, Chaves CR, Queiroz DF, Vasconcelos PRC, Vasconcelos PRL. Effects of L-alanylglutamine on in vivo kidney and blood concentrations of glucose, pyruvate and lactate in rats subjected to unilateral renal ischemia and reperfusion. Rev Bras Nutr Clin. 2002;17:122-5.

13. Torres, JMS, Guimarães SB, Vasconcelos PRL.; Martins MCR, Chaves CR, Vasconcelos PRC. Efeitos metabólicos da L-Alanil-Glutamina em ratos submetidos à isquemia da pata traseira esquerda, seguida de reperfusão. Acta Cir Bras. 2003;18:39-44.

14. Bittl JA, Shine KI: Protection of ischemic rabbit myocardium by glutamic acid. Am J Physiol. 1983;245:406-12.

15. Alessandri B, Doppenberg E, Zauner A, Woodward J, Choi S, Bullock R. Evidence for time-dependent glutamate-mediated glycolysis in head-injured patients: a microdialysis study. Acta Neurochir. 1999;75:25-8.

16. Garcia C, Pithon-Curi CT, Firmano ML, Melo MP, Newsholme P, Curi R. Effects of adrenaline on glucose and glutamine metabolism and superoxide production by rat neutrophils. Clin Sci. 1999;96:549-55.

\section{Correspondence:}

Paulo Roberto Leitão de Vasconcelos

Departamento de Cirurgia

Rua Prof. Costa Mendes, 1608/3 andar

60430-140 Fortaleza-CE Brazil

Phone: (55 85)288-8063

Fax: (5585)288-8064

mcirur@npd.ufc.br
Conflict of interest: none Financial source: none

Received: May 7, 2005

Review: June 9, 2005

Accepted: July 13, 2005

\section{How to cite this article:}

Alves MA, Guimarães SB, Dias DA, Vasconcelos PRC, Coelho VPM, Vasconcelos PRL. Effects of L-alanyl-glutamine upon the blood and kidney biochemical parameters in the rat hind limb model of ischemia/reperfusion. Acta Cir Bras. [serial on the Internet] 2005 Nov-Dec;20(6). Available from URL: http://www.scielo.br/acb

*Color figures available from www.scielo.br/acb 